\title{
MODIFICATION OF ROOT DENSITY IN POT EXPERIMENTS WITH TWO TROPICAL EARTHWORM SPECIES
}

\author{
George G. Brown, ${ }^{1}$ André KretzschmaR ${ }^{2} \&$ José C. Patrón ${ }^{3}$ \\ ${ }^{1}$ Embrapa Florestas, Estrada da Ribeira, km. 111, C.P. 319, Colombo, PR, 83411-000, Brazil. e-mail: \\ browng@cnpf.embrapa.br \\ ${ }^{2}$ INRA-Biométrie, Site Agroparc, 84914, Avignon, France. e-mail: andre.kretzschmar@avignon.inra.fr \\ ${ }^{3}$ Centro de Investigaciones en Ciencias Microbiológicas, Instituto de Ciencias, Benemérita \\ Universidad Autónoma de Puebla, A.P. 1622, Puebla, Pue., 72000, Mexico. \\ e-mail: patron5@siu.buap.mx
}

Brown, G. G., A. Kretzschmar \& J. C. Patrón. 2010. Modification of root density in pot experiments with two tropical earthworm species. Acta Zoológica Mexicana (n.s.), Número Especial 2: 241-259. ABSTRACT. Three greenhouse experiments were performed to assess the role of two common tropical geophagous endogeic earthworm species, Pontoscolex corethrurus and Polypheretima elongata, on root density of several plant species in two soil types, a clayey Andosol and a sandy Alfisol, from Veracruz, Mexico. The equivalent of about $12 \mathrm{~kg}$ dry soil were placed into 201 plastic pots and 3-14 individuals were inoculated to pots planted with common beans (Phaseolus vulgaris), Brachiaria decumbens pasture grass under four P fertilization regimes $\left(0,1.6,8.4\right.$ and $\left.10 \mathrm{~kg} \mathrm{P} \mathrm{ha}^{-1}\right)$ and maize (Zea mays) with or without surface residues. Pots received only one species of earthworms (either P. corethrurus or P. elongata). At harvest, the pots were cut in half and a transparent plastic sheet (overheads) used to draw root and earthworm structures (burrows, casts) in vertical and horizontal (every $5 \mathrm{~cm}$ ) planes. The drawings were scanned, binarized and submitted to image analysis techniques to determine the density of roots, casts and burrows. Root density was generally higher and there was a trend for more even distribution of roots in the soil, both horizontally and vertically, in the presence of earthworms. Nevertheless, few relationships were observed between root density and shoot biomass or the density of earthworm casts and burrows. A more diffuse (less aggregated) root distribution due to earthworms may aid plants in resistance to stress, although the induced changes in the root system may not necessarily lead to greater yields.

Key words: Rhizosphere, earthworm-plant interactions, plant growth, root distribution.

Brown, G. G., A. Kretzschmar \& J. C. Patrón. 2010. Cambios en la densidad de raíces en experimentos en vaso con dos especies de lombrices tropicales. Acta Zoológica Mexicana (n.s.), Número Especial 2: 241-259.

RESUMEN. Se realizaron tres experimentos de invernadero para evaluar el efecto de dos lombrices de tierra geófagas comunes en los trópicos, Pontoscolex corethrurus y Polypheretima elongata, sobre la densidad de raíces de diversas plantas, en dos suelos, un Andosol arcilloso y un Alfisol arenoso, ambos del estado de Veracruz, México. Se colocaron $12 \mathrm{~kg}$ de suelo (peso seco equivalente) en cubetas de plástico de 201 y se añadieron 3-14 lombrices en cubetas sembradas con frijoles (Phaseolus vulgaris), 
Brachiaria decumbens (pasto) bajo cuatro regimenes de fertilización fosfatada $(0,1.6,8.4$ y $10 \mathrm{~kg} P$ $\mathrm{ha}^{-1}$ ) o maíz (Zea mays) con o sin residuos superficiales. Cada cubeta recibió apenas una especie de lombriz ( $P$. corethrurus o $P$. elongata). En la cosecha, se cortaron las cubetas a la mitad y se dibujaron las estructuras de lombrices de tierra (galerias, turrículos) y las raíces en los planos vertical y horizontal (a cada $5 \mathrm{~cm}$ ). Los dibujos fueron escaneados, binarizados y sometidos a análisis de imágenes para determinar la densidad de raíces, turrículos y galerías. En presencia de lombrices, la densidad de raíces fue generalmente mayor y hubo una tendencia de una distribución mas homogénea en el suelo, tanto en los planos vertical como horizontal. Sin embargo, se encontraron pocas correlaciones entre la densidad de las raíces y la biomasa aérea o la densidad de estructuras de lombrices. Una distribución mas difusa (menos agregada) de las raíces debido a la actividad de las lombrices podría ayudar a las plantas aumentando su resistencia al estrés, pero los cambios en el sistema radicular no se reflejarán necesariamente en mejores cosechas.

Palabras clave: Rizósfera, interacciones lombriz-planta, producción vegetal, distribución de raíces.

\section{INTRODUCTION}

The role of earthworms in modifying soil characteristics and plant production is by now well recognized. Over a century ago, Darwin (1881), in his last book, stated that "worm burrows ... greatly facilitate the downward passage of roots of moderate size; and these will be nourished by the humus with which the burrows are lined." Since this initial work, many papers and books have been published on earthworm ecology and relationships with plants and soils, however few detailed descriptions on the interactions between earthworms and plant roots are available.

Roots and earthworms share the same general environment for their development, because in general, what is good for root growth of most plants in soil is also generally good for earthworms (e.g., adequate moisture, little physical impedance, deep, nutrient and organic-rich soils). However, little is known of the direct links between root growth and earthworm distribution in soil. Some earthworm species appear to be very common in the soil zones in closest contact with plant roots (Rovira et al. 1987, Robertson et al. 1994), possibly indicating a preference of this region for their activities. Furthermore, roots are one of the main contributors of the principal food source of earthworms, organic matter (Brown et al. 2000). The higher $\mathrm{C}$ content and populations of microorganisms in the rhizosphere may well act as an attractant to earthworms, but there is little data available to support this notion.

While earthworm migration to and preference for the rhizosphere is still not clearly defined, conversely, plant root migration into earthworm burrows and casts has been better described. Proliferation of roots growing in earthworm casts has been often observed under field conditions in the tropics (Lavelle et al. 1998, G. Brown, personal observation). This is likely due to the high concentrations of readily-available plant nutrients (especially N) in casts (Barois et al. 1999), which often exceed those available in the bulk (uningested) soil (Bartz et al. and Hernández-Castellanos et al., this issue). Concentration of roots in earthworm burrows has also been commonly observed, particularly in lower (esp. B) soil horizons, where compaction 
often limits root penetration (Kretzschmar 1978, Logsdon \& Linden 1992). In this region, the percentage of roots in earthworm burrows versus those outside may be very high (Ehlers et al. 1983, Pitkänen \& Nuutinen 1997, Sveistrup et al. 1997). The origin (and creator) of the original gallery occupied by the root has often been placed into question (Kretzschmar 1998, Springett \& Gray 1997). That is, whether the earthworms first produced the gallery or whether it was previously created by a root or another organism and then used (and expanded) by earthworms is not generally known, particularly in field situations. The answer to this dilemma is most likely that both earthworms and roots develop together, sharing the same general regions of growth and activity, and adapting their own strategies to cope with the soil environment (Kretzschmar 1998).

Both earthworms and roots may thus benefit from each other's presence and activities. The extent of this synergistic interaction and its spatio-temporal dynamics, however, are still largely unknown. The few studies performed so far have addressed primarily the overlap of earthworm and natural channels (macropores) with root presence (e.g., Krebs et al. 1994, Kretzschmar 1978, Pitkänen \& Nuutinen 1997, Hirth et al. 2005), the possible attraction of roots to earthworm channels (Hirth et al. 1997, Springett \& Gray, 1997) and vice-versa (Hirth et al. 1998, Springett \& Gray, 1997). Most of these experiments were performed in temperate regions, with pasture grasses and cereal grains and a limited number of earthworm species. Up to the present, to the authors' knowledge, no study has been performed using tropical earthworm species. Therefore, to assess both the temporal and spatial dynamics of earthworm interactions with roots, three greenhouse experiments were performed, using two common tropical earthworm species, three plant species and multiple sample dates. In all experiments, the main objective was to measure plant growth and production, including root density and distribution in the profile and the influence of earthworms on these parameters.

\section{MATERIAL AND METHODS}

The materials, methods and experimental designs for the three trials performed are detailed in separate publications (Brown et al. 2004, Patrón et al. 1999). Thus we will only briefly state here the main points in the materials and designs used, referring in more detail to the methodology used to quantify and describe root density and distribution in soil.

Two soil types, one a clayey ( $40 \%$ clay, $40 \%$ silt, $10 \%$ sand) Andosol and the other a sandy ( $82 \%$ sand, $10 \%$ clay, $8 \%$ silt) Alfisol were collected from the field by removing the top $10 \mathrm{~cm}$. The former was taken from a tropical rainforest at the Estación de Biología Tropical "Los Tuxtlas" (18 $35^{\circ}$ ' $\mathrm{N}$ and $95^{\circ} 04^{\prime} \mathrm{W}, 380 \mathrm{~m}$ alt.) and had $5.8 \% \mathrm{C}, 0.5 \% \mathrm{~N}$ and a CEC of $30.3 \mathrm{cmol}_{\mathrm{c}} \mathrm{dm}^{-3}$. The latter, taken from a native-grass pasture located at La Víbora (18 $50^{\prime} \mathrm{N}^{\circ} 6^{\circ} 07^{\prime} \mathrm{W}, 35 \mathrm{~m}$ alt.), was severely P-limited 
and had only $0.9 \% \mathrm{C}, 0.1 \% \mathrm{~N}$ and a CEC of $11.7 \mathrm{cmol}_{\mathrm{c}} \mathrm{dm}^{-3}$. More information on the chemical composition of these soils can be found in Hernández-Castellanos et al. (this issue). The soils were partly air-dried, sieved at 5 and then $2 \mathrm{~mm}$ and stored in burlap bags in the greenhouse.

Two pantropical geophagous endogeic earthworm species, Pontoscolex corethrurus (Müller, 1857) and Polypheretima elongata (Perrier, 1872) were chosen for this study. P. corethrurus were taken from a pasture at Plan de las Hayas, from the Los Tuxtlas station and from the Centro de Investigaciones Costeras "La Mancha." $P$. elongata were also collected at the latter site. Both species were placed for several days in the target soils in large plastic boxes before using them for the experiment.

About $12 \mathrm{~kg}$ (oven dry weight equivalent) soil was packed into 20-liter white plastic pots and watered to field capacity ( $\mathrm{pF} 2.0$ ). The sandy savanna soil required little water and was easily packed to $1.2 \mathrm{~g} \mathrm{~cm}^{-3}$ into the pots while the clayey forest soil due to its andic properties retained much water and was packed at a lower bulk density $\left(0.8 \mathrm{~g} \mathrm{~cm}^{-3}\right)$. Certified seeds of Phaseolus vulgaris (bean), Zea mays (maize) and Brachiaria decumbens (pasture grass) were purchased locally and planted in their respective pots. Selected pots planted with maize received $9 \mathrm{~g}$ each (equivalent to 1.36 $\mathrm{T} \mathrm{ha}^{-1}$ ) of maize residues applied on the soil surface. Pots with grass had 0, 1.6 (surface-applied), 8.4 (injected into the root zone) or $10 \mathrm{~kg} \mathrm{ha}^{-1}$ (injected + superficial) $\mathrm{P}$ fertilizer. Control pots had no earthworms inoculated, and the pots with earthworms received a mean of 9-10 P. corethrurus ( 150 indiv. $\mathrm{m}^{-2} ; 4 \mathrm{~g}$ wet weight, gut contents included, equivalent to approx. $60 \mathrm{~g} \mathrm{~m}^{-2}$ ) in treatments with beans or maize, or 3 P. elongata (50 indiv. $\mathrm{m}^{-2}, 4 \mathrm{~g}$ wet weight) in treatments with beans. Pots with $B$. decumbens received either no earthworms, or 9-14 P. corethrurus (mean 150 indiv.

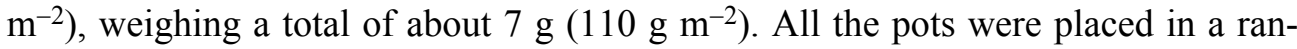
dom order in the greenhouse. The first two experiments were performed at Coatepec, Veracruz while the latter was performed at the Instituto Nacional de Investigaciones Nucleares (ININ), Salazar, Mexico. Ambient temperatures, plant heights and other parameters (plant health) were recorded every few days. The designs used for the three experiments are briefly shown in Table I.

Beans were harvested at $97 \mathrm{~d}, B$. decumbens at $51 \mathrm{~d}$ and maize at 131 and 183 d. At each harvest date plant (height, number of leaves, shoot and root biomass) and earthworm (biomass, number) parameters and soil properties (bulk density, moisture and nutrient contents) were measured according to the methods detailed in Brown et al. (2004) and Patrón et al. (1999).

At each harvest date, the plastic pots were cut in half and clear plastic overheads were used to trace roots and earthworm physical structures (casts and burrows) on the vertical plane, using permanent ink markers of different colors. For beans and maize, additional cuts were performed every $5 \mathrm{~cm}$ on the horizontal plane; for beans there were three horizontal planes $(5,10,15 \mathrm{~cm})$ while for maize there were four $(5,10,15$, 
Table I. Brief summary of the experimental designs used in the study of earthwormplant root interactions.

\begin{tabular}{|c|c|c|c|c|c|c|}
\hline Plant Species & $\begin{array}{l}\text { Earthworm } \\
\text { species }\end{array}$ & $\begin{array}{c}\text { No. } \\
\text { individuals }\end{array}$ & $\begin{array}{c}\text { Biomass } \\
\left(\mathrm{g} \mathrm{m}^{-2}\right)\end{array}$ & $\begin{array}{l}\text { Soil Type } \\
\text { Texture }\end{array}$ & $\begin{array}{l}\text { Harvest } \\
\text { (d) }\end{array}$ & $\mathrm{n}$ \\
\hline $\begin{array}{l}\text { Phaseolus vulgaris } \\
\text { (Black beans) }\end{array}$ & $\begin{array}{l}\text { P. corethrurus } \\
\text { P. elongata }\end{array}$ & $\begin{array}{c}9-10 \\
3 \\
0\end{array}$ & $\begin{array}{l}56.1 \\
60.5\end{array}$ & $\begin{array}{c}\text { Alfisol } \\
\text { sandy loam }\end{array}$ & 97 & $\begin{array}{l}5 \\
8 \\
5\end{array}$ \\
\hline $\begin{array}{l}\text { Brachiaria } \\
\text { decumbens }\end{array}$ & P. corethrurus & $\begin{array}{c}9-14 \\
0\end{array}$ & 110 & $\begin{array}{c}\text { Alfisol } \\
\text { sandy loam }\end{array}$ & 51 & $\begin{array}{l}3 \text { or } 4 \\
3 \text { or } 4\end{array}$ \\
\hline Zea mays (Maize) & P. corethrurus & $\begin{array}{c}9-10 \\
0\end{array}$ & 59.4 & $\begin{array}{c}\text { Andisol } \\
\text { clay }\end{array}$ & 131,183 & $\begin{array}{l}3,4 \\
3,4\end{array}$ \\
\hline $\begin{array}{l}\text { Zea mays (Maize) } \\
+ \text { surface residues }\end{array}$ & P. corethrurus & $\begin{array}{c}9-10 \\
0\end{array}$ & 59.4 & $\begin{array}{l}\text { Andisol } \\
\text { clay }\end{array}$ & 183 & $\begin{array}{l}2 \\
3\end{array}$ \\
\hline
\end{tabular}

$20 \mathrm{~cm} ; 131 \mathrm{~d})$ or five $(5,10,15,20,25 \mathrm{~cm} ; 183 \mathrm{~d})$ planes. Selected pots were chosen from each experiment according to the following criteria: both earthworms and plants were alive at harvest and (for beans and maize) grain was harvested. The number of replicates analysed in each experiment and treatment is shown in Table I.

The drawings were then scanned, producing a digitized black and white image which was then transformed into a binary image. On this image, earthworm structures and roots were separated creating two different files. Both files were then separately submitted to an image analysis technique using the shareware program NIH (National Institute of Health, USA) IMAGE which produced a grid of uniformly sized squares (with a definite number of pixels) to count the number of black pixels (roots \& earthworm structures) in each square, thus giving an estimate of the mean root and earthworm structures density (mean number of black pixels per square).

The spatial distribution of roots (aggregated, uniform and random) was studied in two steps:

1. Variability of root density versus sampling size. The size of the squares used to calculate root density was progressively increased, producing a function, in which the variance $\left(\sigma^{2}\right)$ of the distribution of black pixels within the population of squares was related with the mean value and the size of the squares. This calculation is based on the notion of integral range (Lantuéjoul 2002), considering the variation of the mean value over the whole grid instead of the variation of the mean number of pixels, increasing with the size of the sampling square. The equation describing this function was:

$$
\sigma^{2}=\frac{\mathrm{K} * \text { mean }}{\text { grid } \mathrm{x}}
$$


in which $\mathrm{x}$ is a power factor of the square grid size. A horizontal line would depict that $\sigma^{2}$ is independant of grid size (which is true for $\mathrm{x}=0$, i.e. that the roots are homogeneously distributed). For the intermediate value of $x$, the shape of this function describes the randomness of the distribution of roots. A random distribution of pixels would provide a linear decrease of $\sigma^{2}$ with increasing grid size. As the curve is steeper for the lower values of grid than for upper values, the distribution of roots should be aggregative at small distance.

2. Root spatial distribution. The type of root distribution was studied by using a procedure of dilation which is defined in the image analysis software of the NIH IMAGE program. Any white pixel which had three black pixels of the initial image in its neighborhood got the black value. As objects grew in size, they connected themselves and, consequently, the number of objects decreased. The decrease of object number was then fitted to a Weibull distribution and the two parameters $\alpha$ and $\beta$ of this distribution were estimated by the least square method. An additional parameter $\mathrm{K}$ was estimated which described essentially the density of objects. A typical random distribution of objects would be exactly fitted by a linear regression and the fit to a Weibull distribution depicts the aggregative distribution of roots: roots are more numerous at short distance than would be expected with a stationary distribution. Parameter $\alpha$ indicated the mode of the distribution and the parameter $\beta$ depicted the dispersion of the distribution.

The effect of earthworm additions on root density both in the horizontal (different depths) and vertical planes was assessed by comparing the means with the appropriate controls using ANOVA. The relationship between root density and various other plant parameters (root and shoot biomass, root/shoot ratios), as well as with the density of earthworm structures was explored using linear regression. The regression coefficients of the different treatments obtained from the distribution calculations were also compared using ANOVA. All analyses were performed using the software package SuperAnova ${ }^{\circledR}$ (Abacus Concepts).

\section{Root density}

\section{RESULTS}

The main results of the ANOVA on root density in each experiment are summarized in Table II. In the vertical plane, significant differences were observed only for the experiment with $B$. decumbens, while in the horizontal planes, differences were observed for the beans and maize with residues $(183 \mathrm{~d})$ and for maize without residues at $131 \mathrm{~d}$ (only mean density over whole horizontal profile).

In the beans, $P$. elongata significantly increased root density in the vertical plane (Fig. 1), while for P. corethrurus the difference was not significant. On the other 
Table II. Results of the ANOVA for the presence of earthworms on mean root density in the vertical and horizontal planes and at each depth of the horizontal cuts, for each experiment. ns $=$ not significant, $\mathrm{df}=$ degrees of freedom, $\mathrm{p}=$ level of significance of $\mathrm{F}$ test.

\begin{tabular}{lccc}
\hline \multicolumn{1}{c}{ Plane and Experiment } & df & $\mathrm{F}$ & $\mathrm{p}$ \\
\hline Vertical & & & \\
Phaseolus Beans & 2 & 2.5 & $\mathrm{~ns}$ \\
B. decumbens & 7 & 13.6 & 0.0001 \\
Maize no Res. 131 d & 1 & 0.04 & $\mathrm{~ns}$ \\
Maize no Res. 183 d & 1 & 0.27 & $\mathrm{~ns}$ \\
Maize+Res. 183 d & 1 & 2.81 & $\mathrm{~ns}$ \\
Horizontal & & & \\
Phaseolus Beans & 2 & 4.6 & 0.02 \\
Density at depth & 8 & 1.87 & $\mathrm{~ns}$ \\
Maize no Res. 131 d & 1 & 6.57 & 0.02 \\
Density at depth & 7 & 1.92 & $\mathrm{~ns}$ \\
Maize no Res. 183 d & 1 & 0.4 & $\mathrm{~ns}$ \\
Density at depth & 9 & 0.42 & $\mathrm{~ns}$ \\
Maize+Res. 183 d & 1 & 22.9 & 0.0001 \\
Density at depth & 9 & 3.65 & 0.01 \\
\hline
\end{tabular}

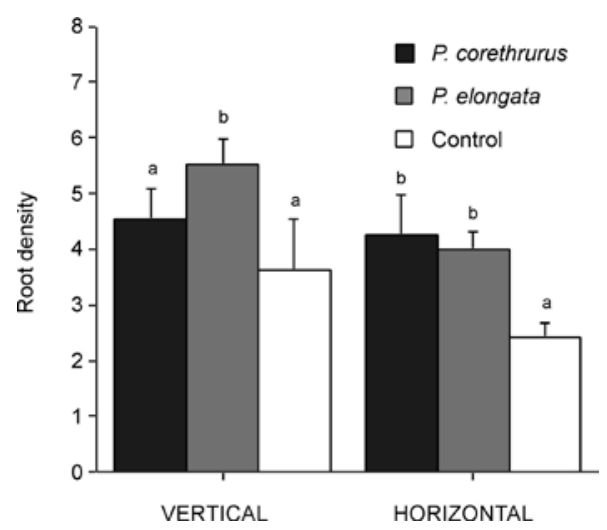

Figure 1. Vertical and horizontal density of bean roots at the final harvest (97 d) in the presence or absence (control) of $P$. corethrurus or $P$. elongata. Different letters above bars indicate significant differences $(\mathrm{P}<0.05)$ between treatments, within each type of cut (vertical, horizontal).

hand, mean root density in the horizontal cuts was significantly higher for both earthworm species (Fig. 1). At $5 \mathrm{~cm}$ in the horizontal cuts, significantly more roots were found in both earthworm treatments compared to controls (Fig. 2). 


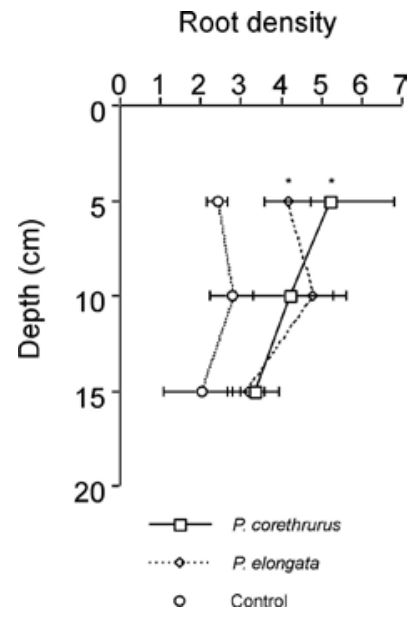

Figure 2. Distribution of bean root density with depth, in the presence or absence (control) of $P$. corethrurus or $P$. elongata. Asterisks $\left(^{*}\right)$ denote significant differences between earthworm and control treatments at $\mathrm{P}<0.05$.

In the maize without residues, root density in the horizontal and vertical planes increased slightly from 131 to $183 \mathrm{~d}$ (Fig. 3), and at $131 \mathrm{~d}$ density in the horizontal plane was significantly higher with $P$. corethrurus. Nevertheless, no significant differences were observed at $183 \mathrm{~d}$ between worm and no-worm treatments. In the maize+residues vertical densities were lower than without residues (Fig. 3). Significantly higher densities were observed with $P$. corethrurus in the horizontal plane but, in the vertical plane, these were not significantly different. Root density in the differ-

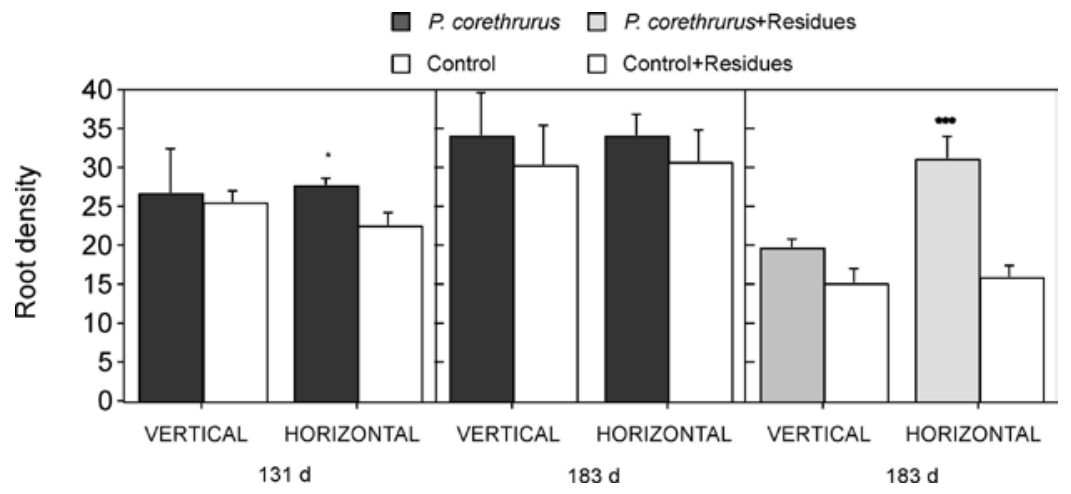

Figure 3. Vertical and horizontal density of maize roots at two harvest dates (131 and $183 \mathrm{~d})$ without residues and with surface-applied maize residues at $183 \mathrm{~d}$ in the presence or absence (control) of $P$. corethrurus. $*=\mathrm{P}<0.05 ; * * *=\mathrm{P}<0.001$. 
ent horizontal cuts (Fig. 4) revealed higher root density with $P$. corethrurus at almost all depths in the treatment with residues at $183 \mathrm{~d}$. In the treatment without residues at $183 \mathrm{~d}$ no significant differences were observed and at $131 \mathrm{~d}$ higher density due to earthworm presence was only found at $20 \mathrm{~cm}$ depth.

Root density values of $B$. decumbens (Fig. 5) were closer to those of beans than of maize, probably due to the shorter length of the experiment. Fertilization increased mean root density significantly, and the highest densities were obtained in the noworm treatments with 8.4 and $10 \mathrm{~kg} \mathrm{P} \mathrm{ha}^{-1}$ (Fig. 5). At these fertilization levels, root density was significantly lower in the presence of earthworms. No difference was observed between density with or without earthworms at 0 or $1.6 \mathrm{~kg} \mathrm{P} \mathrm{ha}^{-1}$.

The results of regressions using plant production parameters and mean overall horizontal and vertical root densities (from all treatments combined or earthworm treatments alone) are shown in Table III. With beans vertical and horizontal densities were significantly (and positively) related with shoot and root biomass. Earthworm effects were only significant when relating vertical density with root biomass in the presence of $P$. elongata, or when relating horizontal density with root biomass in treatments with $P$. corethrurus. In pots with $B$. decumbens, regressions between vertical root density with shoot and root biomass and shoot/root ratios were significant using all data and treatments with $P$. corethrurus. In maize without residues at 131
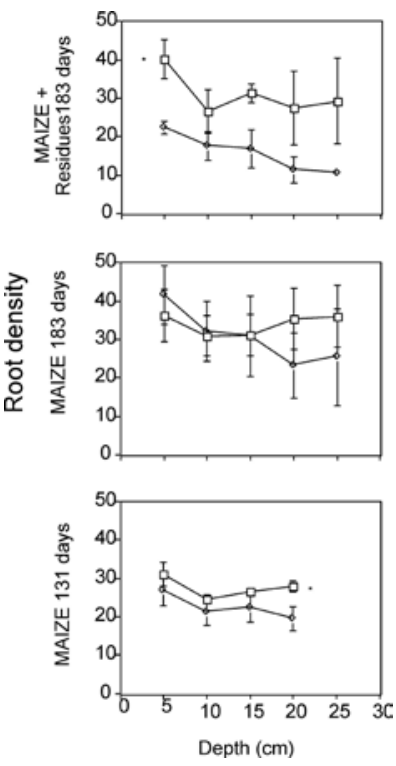

Figure 4. Density distributions of maize roots in horizontal cuts through the pot profile in the presence or absence (control) of $P$. corethrurus, with or without surface-applied maize residues at two harvest dates $(131$ and $183 \mathrm{~d}) . *=\mathrm{P}<0.05 ; * * *=\mathrm{P}<0.001$. 


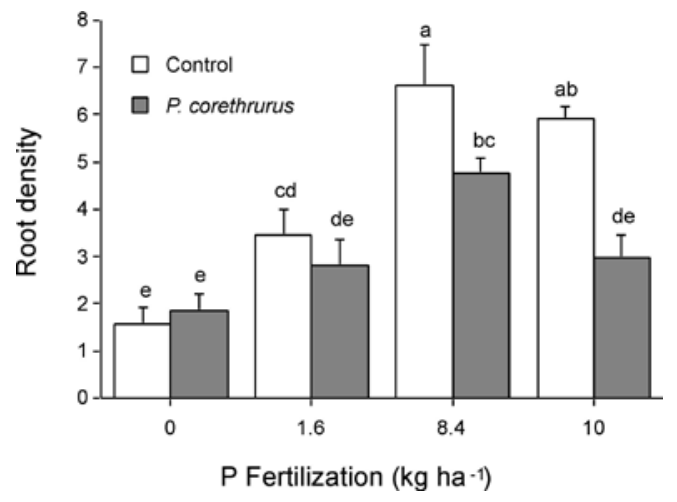

Figure 5. Density of Brachiaria decumbens roots in the presence or absence (control) of $P$. corethrurus under four $\mathrm{P}$ fertilization regimes $\left(0,1.6,8.4\right.$ or $\left.10 \mathrm{~kg} \mathrm{ha}^{-1}\right)$. Different letters above bars indicate significant differences $(\mathrm{P}<0.05)$ between treatments.

Table III. Correlation coefficients of linear regressions of vertical and horizontal root densities with plant parameters for beans, $B$. decumbens and maize, using data from all treatments combined or earthworm treatments separately. Statistical significance as follows: $* * * \mathrm{P}<0.001 ; * * \mathrm{P}<0.01 ; * \mathrm{P}<$ $0.05, \mathrm{~ns}=$ not significant, $\mathrm{ND}=$ not determined. Regression analysis was only performed when $\mathrm{n}>4$.

\begin{tabular}{|c|c|c|c|c|c|}
\hline \multirow[b]{2}{*}{ Plant (date) } & \multirow[b]{2}{*}{ Parameter } & \multirow[b]{2}{*}{ Treatments } & \multirow[b]{2}{*}{$n$} & \multicolumn{2}{|c|}{ Correlation coefficients } \\
\hline & & & & Vertical & Horizontal \\
\hline \multirow[t]{4}{*}{ Phaseolus beans } & Root biomass & All combined & 18 & $0.64 * *$ & ns \\
\hline & & P. corethrurus & 5 & ns & $0.89 *$ \\
\hline & & P. elongata & 8 & $0.79 *$ & $\mathrm{~ns}$ \\
\hline & Shoot biomass & All combined & 18 & ns & $0.58 *$ \\
\hline \multirow[t]{6}{*}{ B. decumbens } & Root biomass & All combined & 25 & $0.69 * * *$ & ND \\
\hline & & P. corethrurus & 12 & $0.73 * *$ & \\
\hline & Shoot biomass & All combined & 25 & $0.84 * * *$ & ND \\
\hline & & P. corethrurus & 12 & $0.77 * *$ & \\
\hline & Shoot/Root & All combined & 25 & $0.78 * * *$ & ND \\
\hline & & P. corethrurus & 12 & $0.70 *$ & \\
\hline \multirow[t]{4}{*}{ Maize (183 d) } & Root biomass & All combined & 8 & $0.84 * *$ & $0.88^{* *}$ \\
\hline & & P. corethrurus & 4 & ns & ns \\
\hline & Shoot/Root & All combined & 8 & $-0.89 * *$ & $-0.84 * *$ \\
\hline & & P. corethrurus & 4 & ns & $-0.96^{*}$ \\
\hline \multirow[t]{3}{*}{$\begin{array}{l}\text { Maize+Residues } \\
\qquad(183 \mathrm{~d})\end{array}$} & $\begin{array}{l}\text { Root biomass at } \\
\text { diff. depths }\end{array}$ & All combined & 25 & ND & $0.63 * * *$ \\
\hline & Shoot/Root & All combined & 5 & ns & $-0.99 * *$ \\
\hline & Grain biomass & All combined & 5 & $-0.95^{*}$ & ns \\
\hline
\end{tabular}


d, no significant effects were observed for any of the parameters studied. At $183 \mathrm{~d}$ in treatments without residues, root density was significantly related with root biomass and shoot/root ratios (negative). Significant effects of $P$. corethrurus were only observed on shoot/root ratios (negative). In the presence of residues, few relationships with root density were observed; positive with root biomass and negative with shoot/ root ratios using horizontal data, and negative with grain yield using vertical data for all treatments.

\section{Earthworm structure density}

The mean density of earthworm structures (casts and burrows) in the different experiments and treatments is given in Table IV. Few earthworm structures were visible in the vertical plane of pots with $B$. decumbens. Similarly, in the $131 \mathrm{~d}$ harvest of maize, density of structures was low, although it varied with depth; highest density was observed at $15 \mathrm{~cm}$ and lowest at $5 \mathrm{~cm}$. At $183 \mathrm{~d}$ without residues, density of earthworm structures in both vertical and mean horizontal planes was smaller than with residues; furthermore, at each horizontal plane, density with residues was higher than without. At the 10 and $15 \mathrm{~cm}$ plane, densities were the highest, indicating this region as their preference for activity. The mean obtained from the horizontal cuts was higher than with the vertical in the treatment with residues, perhaps indicating relatively greater vertical activity. With beans, structure density increased with depth, from a mean of 11.0 and 2.0 at $5 \mathrm{~cm}$ with $P$. corethrurus and $P$. elongata, to 30.2 and 18.9 , respectively at $15 \mathrm{~cm}$. Mean density in the vertical plane tended towards higher values than obtained in the horizontal plane, in presence of both species, indicating relatively greater horizontal activity.

The regressions of earthworm structure densities with root densities and other plant parameters revealed very few relationships. For the horizontal structure density, root density of beans in pots with $P$. elongata was negatively related to earthworm structures $(r=-0.42, p<0.05)$. For the vertical structure density, bean shoot and pod biomass were strongly related to $P$. corethrurus structures $(r=0.96, p<0.01$ and $r=0.97, p<0.05$, respectively). In maize pots without residues at $183 \mathrm{~d}$ the biomass of shoots was strongly related to earthworm structure density in the horizontal plane $(r=0.99, p<0.05)$. For $B$. decumbens, no significant relationships were observed for either planes (vertical or horizontal).

\section{Root spatial distribution}

The use of the variance-vs-density parameter for the description of root distribution can be illustrated as shown in Table V. The effect of the presence or absence of residues is depicted by the fact that, in absence of residues, the parameter $\mathrm{K}$ decreases with depth (showing the decrease of root density, where at the same time the param- 


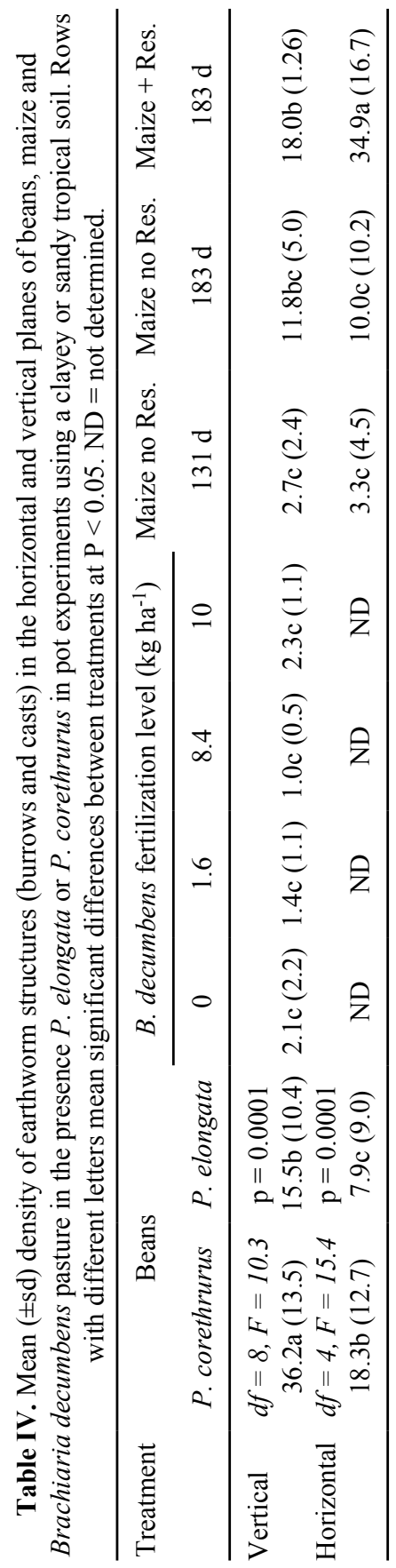


Table V. Variation with depth and effect of residue application and earthworm presence in maize on the values of $\mathrm{K}$ and $\mathrm{x}$ for the model Variance vs. Density.

\begin{tabular}{ccccc}
\hline $\begin{array}{c}\text { Residue } \\
\text { treatment }\end{array}$ & $\begin{array}{c}\text { Earthworm } \\
\text { treatment }\end{array}$ & $\begin{array}{c}\text { Depth } \\
(\mathrm{cm})\end{array}$ & $\mathrm{K}$ & $\mathrm{x}$ \\
\hline No residues & control & 5 & 41.68 & 0.54 \\
& & 10 & 32.02 & 0.54 \\
& & 15 & 30.71 & 0.56 \\
& & 20 & 23.19 & 0.58 \\
No residues & +earthworms & 25 & 25.35 & 0.58 \\
& & 5 & 36.16 & 0.56 \\
& & 10 & 30.95 & 0.57 \\
& & 15 & 31.06 & 0.54 \\
& & 20 & 35.32 & 0.52 \\
+ Residues & Control & 25 & 36.05 & 0.59 \\
& & 5 & 22.35 & 0.57 \\
& & 10 & 17.52 & 0.58 \\
& & 15 & 16.85 & 0.60 \\
& & 20 & 11.45 & 0.57 \\
& & 25 & 10.41 & 0.59 \\
& & 5 & 40.20 & 0.537 \\
& & 10 & 26.60 & 0.6 \\
& & 15 & 31.30 & 0.547 \\
& & 20 & 27.50 & 0.573 \\
& & 25 & 29.20 & 0.534 \\
\hline
\end{tabular}

eter $\mathrm{x}$ increases with depth, showing that the aggregated distribution is more marked with depth. The introduction of earthworms disturbs the effect of depth on root density and erases the effect of aggregated distribution; the global effect of earthworms seems to be a randomization of root densities which favors the efficiency of soil exploration by roots.

When the second method of root distribution description was used, in treatments with and without earthworms in maize, no clear tendency was observed; nevertheless, in Fig. 3 and 4 there was a clear difference between vertical and horizontal cuts. In the latter, the parameter $\beta$ decreased with $\alpha$ (linked to density), meaning that with increasing number of root fragments, the more aggregated was their distribution.

\section{DISCUSSION}

Root morphology at a given time is a function of plant genotype, past and present soil properties, and plasticity of the given phenotype, i.e. genotype $\mathrm{x}$ environment interactions. Changes in environmental conditions such as soil structure, texture, water 
and nutrient availability, temperature, microbial and faunal populations and activity, carbon and additional energy inputs can affect root growth of a given plant (Smucker 1993). Roots can sense soil water, nutrient and mechanical conditions and send signals (including various plant hormones) to shoots, which can ultimately regulate plant growth (Aiken \& Smucker 1996). Since nutrients and water are supplied by the root system to the shoot, it is the density, distribution and activity of roots which largely determine plant production (Brown \& Scott 1984).

Root systems consisting of mostly fine roots (such as those of grasses), develop greater surface areas and root densities at lower relative $\mathrm{C}$ costs to the plant (Eissenstat 1992) and permit a better utilization of soil resources and resistance to stress. In the present experiment, the fibrous root system of maize with extensive lateral branching (many secondary roots) resulted in much higher root densities than with beans or $B$. decumbens. The earlier harvest of the latter plant and the different rooting strategy of the former (tap-rooted dicotyledonous, deeper and fewer roots) are probably the main factors responsible for these differences, although the difference in fertility of the soils used and earthworm activity may also play a role in the observed differences. The presence of residues in maize treatments reduced root density, particularly in the top $10 \mathrm{~cm}$. This could be due to the higher availability of nutrients leaching from the residues or to greater protection from wetting-drying cycles, which tend to increase root branching (Smucker \& Aiken 1992).

If denser root systems favor plant performance (Eissenstat 1992), a positive relationship between root density and plant yields should result. These relationships were in fact, generally observed in most of the present experiments, although in some cases the relationships were not so clear cut and regressions were not significant. Furthermore, the effects were not always the same for different plant parts and their relative biomass. For instance, with maize at the $183 \mathrm{~d}$ harvest, the relationships between root biomass and root density were positive, but the relationship with root:shoot ratios was always negative, indicating that higher root densities, i.e., higher energy of the plant invested in root growth, resulted in lower shoot yields (Brown et al. 2004). Conversely, with $B$. decumbens, positive relationships were observed between root density and root and shoot biomass and root:shoot ratios, despite earthworm-induced decreases in root density in some treatments.

Earthworm effects on root density were mainly positive with maize and beans, indicating a greater volume of soil being exploited by the plant in these treatments. With beans earthworms, particularly P. elongata, had significant (positive) effects on plant height, shoot and root growth, but no effects on bean grain yields (Brown et al. 2004). On the other hand, with maize, earthworm effects on plant yield parameters were frequently negative compared with no-earthworm controls (Brown et al. 2004). Perhaps in the treatments with earthworms, the greater investment in roots was to the detriment of shoot and grain biomass. Furthermore, the natural richness (fertility) of 
this forest soil and the lower need of the plant for high investment in root production may mean that the earthworms were tilting the plant energy investments towards less useful root production.

With $B$. decumbens earthworm effects on root density were negative at the two higher fertilization levels. Furthermore, earthworm activity (as observed in the density of earthworm burrows and casts) in this experiment was slightly negatively related with root density, indicating that treatments with more earthworm activity had lower root densities. Root biomass however, was only negatively affected by earthworms in the treatment with the highest fertilization level (Patrón et al. 1999). In this treatment, both earthworms and fertilization also decreased VAM infection of roots reducing any possible benefits of this symbiosis to the plant (Patrón et al. 1999, Brown et al. 2000).

Not always have earthworm activities and positive effects on root density been positively related with plant yields. For instance, in Dutch apple orchards, van Rhee (1977) found a greater number of small $(<0.5 \mathrm{~mm}$ diam.) roots in orchards inoculated with earthworms, but few differences in apple yields. On the other hand, many previous experiments have reported earthworm-induced increases in root growth and biomass both in field and greenhouse experiments, although roots generally received less attention than the above ground parts in most trials (Brown et al. 1999, Scheu 2003). In no-tillage agroecosystems, Edwards \& Lofty $(1978,1980)$ and Springett (1985) showed that root biomass increases and depth distributions depended on the earthworm species present. Anecic species such as Aporrectodea longa and Lumbricus terrestris increased root biomass at greater depths than shallow burrowing species. This is likely because anecic species burrow more vertically and produce deeper channels which roots can follow (Ehlers et al. 1983). Roots can also enter and follow the mostly horizontal burrows produced by geophagous endogeic species such as the two species used in the present experiment, and the probability of encountering these channels is likely to be higher than that of encountering vertical burrows (Tisdall \& McKenzie 1995). In the present experiment roots were often found in earthworms burrows, particularly in the experiment with beans. More research is needed to determine the reasons why roots choose to follow burrows in some soils and not in others, and which type, size, abundance, distribution and orientation of burrows is best for the growth of a particular plant.

Root maps and spatial analysis of roots in the field have shown that root distributions are seldom uniform (homogeneous) and are often clustered along pedon faces and biopores (Smucker 1993). These heterogeneous (and often aggregated) distributions can result from compaction and regions rich in water and nutrients (Pierret et al. 2007). This spatial clustering results in a lower soil volume exploited by the roots and can increase the potential for greater biotic and abiotic stress (Smucker 1993). In the present experiment, roots were not uniformly distributed and earthworms had little 
effect on root distribution, but when significant differences occurred, the roots tended to be slightly more homogeneously distributed (less aggregated) in the earthworm treatments. The reasons for these differences in root distribution due to earthworm activity are not known. The soil-mixing activities of earthworms may be considered as a soil homogenization process, but only when the soil is in a heterogeneous state (not the case in the present experiment). In contrast, the creation of hot-spots of nutrient availability (castings) and galleries within the soil (burrows) are activities which may lead to a concentration of roots, increasing heterogeneity (and aggregation). Ultimately, it is the balance of these two types of activities (homogenization and aggregation), as affected by the earthworm community, plant(s) and soil type in question, which will dictate the effects of earthworms on plant root density and distribution in soil.

In the present paper, we have shown that earthworms affected both vertical and horizontal root density in soil, with a tendency to create more even root distributions. Thus, plants growing in the presence of earthworms may benefit not only from possible changes in soil structure (aggregation, biopores for root elongation), fertility (higher nutrient content in casts) and biological characteristics (populations of pathogens, parasites and beneficial organisms), but also from a higher root density in some instances, and a consequently greater volume of soil under exploitation by roots. This, in addition to a more even distribution of roots in the soil profile, and a concentration of roots in burrows and casts may all play an important role in enhancing plant resistance to stress in the presence of earthworms. In fact, root density measurements were generally well correlated with root biomass, although in only a few cases was it related with shoot biomass.

We are still far from understanding the way in which plant roots and earthworms interact, and what effects this will have on yields. This is largely because even the mechanisms responsible for root branching and the photosynthetic costs associated with the production and maintenance of these branches are essentially unknown (Smucker 1993). Furthermore, there is still much to learn about the impact of earthworms on soil physical, chemical and biological soil properties and the stability, durability and spatial distribution of these effects. Computer Assisted Tomography (CAT-scanning) (e.g., Capowiez et al. 1998, Langmaack et al. 1999), mini-rhizotrons (Springett \& Gray 1997) and other non-destructive descriptive techniques that can be repeated in time, combined with destructive sampling and image analysis are a good start in describing interactions of earthworms and roots (Krebs et al. 1994, Hirth et al. 1997, Springett \& Gray 1994). However, there is also need for even more basic research since earthworm burrowing behavior in different soils, the composition of the linings, the amount of below vs. above-ground castings, the chemical, physical and microbiological characteristics of casts and their changes over time and the amount of overlap of earthworm activity with rhizospheres of different plants are still unknown for many earthworm species, particularly in tropical regions. 


\section{ACKNOWLEDGEMENTS}

The authors would like to thank I. Barois, E. Aranda, S. Irisson, A. Martínez, A. Angeles, J. Bueno, G. Pérez, J. Huesca, Ana Maria, Ing. Fabre, T. Goszczynski, D. Rosalio, P. Sánchez, J. Benitez, C. Gutiérrez, M. Brossard and others who helped at various stages of these experiments. The comments of four anonymous reviewers are gratefully acknowledged. Financial resources and/or facilities for the present work were provided by the EU (STD-3), IRD (ex-ORSTOM), INRA, the Instituto de Ecología, A.C., CONACYT, ININ, UNCADER and CNPq.

\section{LITERATURE CITED}

Aiken, R. M. \& A. J. M. Smucker. 1996. Root system regulation of whole plant growth. Annual Review of Phytophathology. 34: 325-346.

Brown, G. G., B. Pashanasi, C. Villenave, J. C. Patrón, B. K. Senapati, S. Giri, I. Barois, P. Lavelle, E. Blanchart, R. J. Blakemore, A. V. Spain \& J. Boyer. 1999. Effects of earthworms on plant production in the tropics. Pp.87-147. In: P. Lavelle, L. Brussaard and P. F. Hendrix (Eds). Earthworm management in tropical agroecosystems. CAB International, Wallingford.

Brown, G. G., I. Barois \& P. Lavelle. 2000. Regulation of soil organic matter dynamics and microbial activity in the drilosphere and the role of interactions with other edaphic functional domains. European Journal of Soil Biology. 36: 177-198.

Brown, G. G., J. C. Patrón, I. Barois \& P. Lavelle. 2004. Tropical earthworm (Pontoscolex corethrurus: Glossoscolecidae; Polypheretima elongata: Megascolecidae) effects on common bean (Phaseolus vulgaris) and maize (Zea mays) production under greenhouse conditions. Pp. 313-339. In: S. H. S Hanna and W. Z. A. Mikhail (Eds.). Soil zoology for sustainable development in the 21st century. Palm Press, Cairo.

Brown, D. A. \& H.D. Scott. 1984. Dependence of crop growth and yield on root development and activity. Pp. 101-136. In: S. A. Barber and D. R. Bouldin (Eds.). Roots, nutrient and water influx, and plant growth. ASA Special Publication No. 49, Madison.

Capowiez, Y., A. Pierret, O. Daniel, P. Monestiez \& A. Kretzschmar. 1998. 3D skeleton reconstructions of natural earthworm burrow systems using CAT scan images of soil cores. Biology and Fertility of Soils. 27: 51-59.

Darwin, C. 1881. The formation of vegetable mould through the action of worms, with observations on their habits. Murray, London.

Edwards, C. A. \& J. R. Lofty. 1978. The influence of arthropods and earthworms upon root growth of direct drilled cereals. Journal of Applied Ecology. 15: 789-795.

Edwards, C. A. \& J. R. Lofty. 1980. Effects of earthworm inoculation upon the root growth of direct drilled cereals. Journal of Applied Ecology. 17: 533-543.

Ehlers, W., U. Kopke, F. Hesse \& W. Bohm. 1983. Penetration resistance and root growth of oats in tilled and untilled loess soil. Soil \& Tillage Research. 3: 261-275.

Eissenstat, D. M. 1992. Costs and benefits of constructing roots of small diameter. Journal of Plant Nutrition. 15: 753-782.

Hirth, J. R., B. M. McKenzie \& J. M. Tisdall. 1997. Do the roots of perennial ryegrass elongate to biopores filled with the casts of endogeic earthworms? Soil Biology \& Biochemistry. 29: 529-531.

Hirth, J. R., B. M. McKenzie \& J. M. Tisdall. 1998. Roots of perennial ryegrass (Lolium perenne) influence the burrowing of the endogeic earthworm, Aporrectodea rosea. Soil Biology \& Biochemistry. 30: 2181-2183. 
Hirth, J. R., B. M. McKenzie \& J.M. Tisdall. Ability of seedling roots of Lolium perenne L. to penetrate soil from artificial biopores is modified by soil bulk density, biopore angle and biopore relief. Plant and Soil. 272: 327-336.

Krebs, M., A. Kretzschmar, U. Babel, J. Chadœf \& M. Goulard. 1994. Investigations on distribution patterns in soil: basic and relative distributions of roots, channels and cracks. Pp. 437-449. In: A. J. Ringrose-Voase and G. S. Humphreys (Eds.). Soil micromorphology: studies in management and genesis. Elsevier, Amsterdam.

Kretzschmar, A. 1978. Quantification écologique des galeries de lombriciens. Techniques et premières estimations. Pedobiologia. 18: 31-38.

Kretzschmar, A. 1998. Earthworm interactions with soil organization. Pp. 163-176. In: C. A. Edwards (Ed.). Earthworm ecology. St. Lucie Press, Boca Raton.

Langmaack, M., S. Schrader, U. Rapp-Bernhardt \& K. Kotzke. 1999. Quantitative analysis of earthworm burrow systems with respect to biological soil-structure regeneration after soil compaction. Biology and Fertility of Soils. 28: 219-229.

Lantuéjoul, C. 2002. Geostatistical simulation, models and algorithms. Springer Verlag, Heidelberg.

Lavelle, P., I. Barois, E. Blanchart, G. G. Brown, L. Brussaard, T. Decaëns, C. Fragoso, J. J. Jiménez, K. Ka Kajondo, M. A. Martínez, A. G. Moreno, B. Pashanasi, B. K. Senapati, C. Villenave. 1998. Earthworms as a resource in tropical agroecosystems. Nature \& Resources. 34: 26-41.

Logsdon, S. D. \& D. R. Linden. 1992. Interactions of earthworms with soil physical conditions influencing plant growth. Soil Science. 154: 330-337.

Patrón, J. C., P. Sánchez, G. G. Brown, I. Barois, M. Brossard \& C. Gutiérrez. 1999. Phosphorus in soil and Brachiaria decumbens plants as affected by the geophagous earthworm Pontoscolex corethrurus and P fertilization. Pedobiologia. 43: 547-556.

Pierret, A., C. Doussan, Y. Capowiez, F. Bastardie \& L. Pagès. 2007. Root functional architecture: a framework for modeling the interplay between roots and soil. Vadose Zone Journal. 6: 269-281.

Pitkänen, J.\& V. Nuutinen. 1997. Distribution and abundance of burrows formed by Lumbricus terrestris L. and Aporrectodea caliginosa Sav. in the soil profile. Soil Biology \& Biochemistry. 29: 463-467.

Robertson, L. N., B. J. Radford, B. Bridge, D. McGarry, R. J. Blakemore \& M. Sabag. 1994. Tropical earthworms under cropping in Queensland. Pp. 33-34. In: C. E. Pankhurst (Ed.). Soil Biota. Management in sustainable farming systems. Poster Papers. CSIRO, East Melbourne.

Rovira, A. D., K. R. J. Smettem \& K. E. Lee. 1987. Effect of rotation and conservation tillage on earthworms in a red-brown earth under wheat. Australian Journal of Agricultural Research. 38: 829-834.

Sackville-Hamilton, C. A. G. \& J. M. Cherret. 1991. The development of clover and ryegrass root systems in a pasture and their interaction with the soil fauna. Pp. 291-300. In: D. Atkinson (Ed.). Plant root growth. An ecological perspective. Blackwell Scientific Publications, Oxford.

Scheu, S. 2003. Effects of earthworms on plant growth: patterns and perspectives. Pedobiologia. 47: 846-856.

Smucker, A. J. M. 1993. Soil environmental modifications of root dynamics and measurement. Annual Review of Phytopathology. 31: 191-216.

Smucker, A. J. M. \& R. M. Aiken. 1992. Dynamic root responses to water deficits. Soil Science. 154: 281-289.

Springett, J.A. 1985. Effects of introducing Allolobophora longa Ude on root distribution and some soil properties in New Zealand pastures. Pp. 399-407. In: A. H. Fitter, D. Atkinson, D. J. Read and M. B. Usher (Eds.). Ecological interactions in Soil. Blackwell, London. 
Springett, J. A. \& R. Gray. 1994. The distribution of pasture roots and earthworm burrows in the soil profiles of a conventional and organic dairy farm. Pp. 137-138. In: C. E. Pankhurst (Ed.). Soil Biota. Management in sustainable farming systems. Poster Papers. CSIRO, East Melbourne.

Springett, J. A. \& R. Gray. 1997. The interaction between plant roots and earthworm burrows in pasture. Soil Biology \& Biochemistry. 29: 621-625.

Tisdall, J. M. \& B. M. McKenzie. 1995. Impact of earthworms on soil physical properties. Pp. 59-66. In: M. Temple-Smith and T. Pinkard (Eds.). The role of earthworms in agriculture and land management. Department of Primary Industry and Fisheries, Tasmania, Technical Report 1/96.

van Rhee, J. A. 1977. A study of the effect of earthworms on orchard productivity. Pedobiologia. 17: 107-114. 